\title{
Making lawyers moral? Ethical codes and moral character
}

\author{
Donald Nicolson* \\ The Law School, University of Strathclyde
}

This article argues that professional codes of conduct cannot perform the important task of ensuring that lawyers uphold high ethical standards. Instead, moral behaviour by lawyers requires the development of fixed behavioural attributes relevant to legal practice - what may be called a lawyer's professional moral character. At the same time, however, along with other factors, professional codes are important in that they can either contribute to or detract from the successful development of professional moral character. If so, it is argued that in order to have the best chance of assisting the character development of lawyers, codes should neither take the form of highly detailed or extremely vague, aspirational norms, but should instead guide ethical decision-making by requiring them to consider a wide range of contextual factors when resolving ethical dilemmas.

\section{INTRODUCTION}

To a large extent, access to justice, and the quality of law and the legal process is in the hands of legal practitioners who can (and frequently do) cause much harm in their professional activities. ${ }^{1}$ For example, treating law purely as a business can lead to citizens going unrepresented or being poorly represented. Conversely, overzealous representation and loyalty to clients may harm opponents, affected third parties, the administration of justice, and the general public interest. Accordingly, at least since the realisation that most Watergate miscreants were trained lawyers, professional legal ethics has been taught and academically debated in the United States. A similar willingness to take ethics seriously has spread more recently to Canada, Australia and New Zealand.

* Earlier versions of this article were presented at the 2000 SPTL conference at the University of London and at staff seminars at the Universities of Edinburgh and Glasgow. I would like to thank Susan Robb and Christine Rae for their research help, and Aileen $\mathrm{McHarg}$ for her patience and perceptive assistance in discussing and commenting on various drafts.

1. See eg D L Rhode 'Institutionalising Ethics' (1994) Case W Res LR 665; D Nicolson and J Webb Professional Legal Ethics: Critical Interrogations (Oxford: Oxford University Press, 1999), esp ch 6. 


\section{Legal Studies}

In the United Kingdom, the general public has long been sceptical about the integrity of lawyers, ${ }^{2}$ while consumer and government concerns about their morality, access to justice, and the quality of legal services have led to increased regulation ${ }^{3}$ and calls for ethics to become central to legal education. ${ }^{4}$ However, influenced by legal formalism's banishment of all questions of morality and justice from the study and teaching of law, as well as by the traditional distinction between 'academic' and 'vocational' issues in legal education, academics have until very recently almost ${ }^{5}$ totally ignored lawyers' ethics. Admittedly, there has a relatively long-standing interest in related 'macro' ethical issues, such as access to justice, the meaning of professionalism, and the existence and justifiability of restrictive practices. ${ }^{6}$ But, by contrast, discussion of the ethical dilemmas raised by legal practice, such as whether lawyers should act for any client irrespective of moral considerations, how far they should go in pursuing client interests, whether there should be limits to client confidentiality and how to reconcile conflicts of interest, has been largely confined to descriptive accounts written by and for practitioners. ${ }^{7}$

2. See eg Shakespeare's Dick the Butcher in Henry VI, Part II, Act 4, Scene II: 'The first thing we do, let's kill all the lawyers'; Jonathan Swift's description of lawyers as a 'society of men ... bred up from youth in the art of proving by words multiplied for the purpose, that white is black and black is white, according as they are paid': Gulliver's Travels ch 5; John Stuart Mill's complaint that '[the lawyer] hires himself out to do injustice or frustrate justice with his tongue' in J Bowring (ed) The Works of Jeremy Bentham (Edinburgh: William Tait, 1843) vol 7, p 479; the scorn heaped on lawyers by Dickens (Bleak House, Great Expectations) and Trollope (The Three Clerks, Phineas Redux).

3. Nicolson and Webb, above n 1, ch 4; text accompanying nn 28-33; and for more recent developments, see K Economides and J Webb 'Editorial' (2003) 6 Legal Ethics 127 at 129.

4. The Lord Chancellor's Advisory Committee on Legal Education and Conduct First Report on Legal Education and Training (London: ACLEC, 1996) paras 1.19-1.20; The Law Society of England and Wales Second Consultation on a New Training Framework Review for Solicitors (London: The Law Society, 2003) pp 21-22.

5. But cf R Tur 'Profession in Crisis?' Scots Law Times, 18 August 1989, p 297, ‘An Introduction to Lawyers' Ethics' (1992) 10 Journal of Professional Legal Education 217, 'Confidentiality and Accountability' (1992) 1 Griffith LR 73 and 'Accountability and Lawyers' in R Chadwick (ed) Ethics and the Professions (Aldershot: Avebury, 1994). 6. See eg M Zander Lawyers and the Public Interest (London: Weidenfeld and Nicolson, 1968) and A Matter of Justice: The Legal System in Ferment (London: Tauris Publishing, 1988); R Abel The Legal Profession in England \& Wales (London: Basil Blackwell, 1988) and English Lawyers Between Market and State: The Politics Of Professionalism (Oxford: Oxford University Press, 2003); M Burrage 'From a Gentlemen's to a Public Profession: Status and Politics in the History of English Solicitors' (1996) 3 International Journal of the Legal Profession 45; A Paterson 'Professionalism and the legal services market' (1996) 3 International Journal of the Legal Profession 137.

7. Eg W Boulton Conduct and Etiquette at the Bar (London: Butterworths, 6th edn, 1975); T Lund A Guide to the Professional Conduct and Etiquette of Solicitors (London: The Law Society, 1960); P M K Bird and J B Weir The Law, Practice and Conduct of Solicitors (London: Waterlow Publishers, 1989); D Napley The Technique of Persuasion (London: Sweet \& Maxwell, 4th edn, 1991) ch II, though see the more critical contributions of D Pannick Advocates (Oxford: Oxford University Press, 1992); and A Phillips Professional Ethics for Scottish Solicitors (Edinburgh: Butterworths, 1990). 
In the last ten years, however, academic interest in 'micro' ethics has mushroomed. Edited collections ${ }^{8}{ }^{8}$ full-length books, ${ }^{9}$ a special edition of the International Journal of the Legal Profession, ${ }^{10}$ and articles in assorted journals ${ }^{11}$ have all appeared, along with the 1998 launch of Legal Ethics, ${ }^{12}$ the establishment of the SPTL (now SLS) Practice, Profession and Ethics subjection, and most recently Exeter University's hosting of the First International Conference on Legal Ethics. ${ }^{13}$ In broad terms, ${ }^{14}$ this burgeoning debate over micro ethics has addressed one or other of two concerns: the 'what' and the 'how' of lawyers' ethics. The former is concerned with the content of lawyers' ethics, looking at how lawyers resolve, but more frequently at how they ought to resolve, the ethical issues they face in practice. The latter addresses the equally important question of how to ensure that lawyers actually uphold whatever substantive ethical norms are regarded as appropriate. Indeed, for those, like myself, who doubt whether there are ever any categorically correct answers to difficult ethical problems, the slightly different question of how to ensure that lawyers at least care about and are committed to acting morally seems more critical than attempting to define ethical behaviour. Consequently, it is this issue which is the focus of this article.

Historically, while Parliament and the courts have occasionally, and on an ad hoc basis, laid down legal rules governing the behaviour of lawyers, particularly solicitors, within the profession itself the centuries-old patrician, noblesse oblige $^{15}$ or gentleman's tradition ${ }^{16}$ regarded ethical standards as guaranteed by

8. R Cranston (ed) Legal Ethics and Professional Responsibility (Oxford: Clarendon Press, 1995); S Parker and C Sampford (eds) Legal Ethics and Legal Practice (Oxford: Clarendon Press, 1995); K Economides (ed) Ethical Challenges to Legal Education and Conduct (Oxford: Hart Publishing, 1998).

9. Nicolson and Webb, above $\mathrm{n} 1$; A Boon and J Levin The Ethics and Conduct of Lawyers in England and Wales (Oxford: Hart Publishing, 1999); R O'Dair Legal Ethics: Text and Materials (London: Butterworths, 2001); J Griffiths-Baker Serving Two Masters: Conflicts of Interest in the Modern Law Firm (Oxford: Hart Publishing, 2002). See also the empirical studies of lawyer behaviour cited below $n 73$, which touch on ethical issues.

10. Vol 4 (1997).

11. In addition, to those in Legal Ethics, see D R F O'Dair 'Ethics by the Pervasive Method - The Case of Contract' (1997) 17 LS 305; L Sheinman 'Looking for Legal Ethics' (1997) 4 International Journal of the Legal Profession 139; M Blake and A Ashworth 'Some Ethical Issues in Prosecuting and Defending Criminal Cases' [1998] Crim LR 16; D A Ipp 'Lawyers' Duties to the Court' (1998) 114 LQR 63; D Nicolson and J Webb 'Taking Lawyers' Ethics Seriously' (1999) 6 International Journal of the Legal Profession 109.

12. Hart Publishing.

13. See $S$ Nelson 'Reflections from the International Conference on Legal Ethics from Exeter' (2004) 7 Legal Ethics 17.

14. Cutting across them and informing both are discussions of ethical theory: see eg J Webb 'Being a Lawyer/Being a Human Being' (2002) 5 Legal Ethics 130; D Nicolson 'The Theoretical Turn in Professional Legal Ethics' (2004) 7 Legal Ethics 17.

15. D Luban 'The Noblesse Oblige Tradition in the Practice of Law' (1988) 41 Vand LR 717. 16. Cf Burrage, above $\mathrm{n} 6$; A Thornton 'The Professional Responsibility and Ethics of the English Bar' in Cranston, above n 8, pp 56-57. For residual echoes of this tradition, see eg Lund, above n 7, p 54; Queen v O'Connell (1844) 7 Ir LR 261 at 312; Smith v Smith (1882) 7 PD 84 at 89; Rondel v Worsley [1969] 1 AC 191, 227; below n 69 and accompanying text. 


\section{Legal Studies}

the existence of universal, a priori principles, which were correctly understood and applied because of lawyers' common social background, informal peer pressures, judicial oversight and unwritten systems of etiquette. Formal controls were regarded as otiose given that, as gentlemen and therefore men of honour, lawyers instinctively knew how to behave. At most what was needed was to control entry into the profession so that only those made of the 'right stuff' gained the privilege of practising. Most professions, however, promulgate written rules governing their members' behaviour, usually systematised in a single 'code of conduct' and (at least theoretically) backed up by sanctions. Although semiofficial texts on ethics and etiquette were already in existence, ${ }^{17}$ from 1974 the British legal profession began to follow suit and now all four branches have a code or something similar. ${ }^{18}$

No doubt, this code-making activity ${ }^{19}$ can be viewed cynically as an attempt to portray lawyers as honourable, reliable and ethical, and hence worthy of the respect and high financial rewards which accompany professional status, and/ or as a desperate attempt to ward off state intervention in a climate of state and public hostility. However, less cynically, social contractarians regard codes as the written manifestation of the bargain between profession and society, under which the former agrees to ensure certain ethical standards in return for the advantages of professional status. ${ }^{20}$ Although, it might be true that codes (and their enforcement $)^{21}$ tend to prioritise the interests of professional elites, ${ }^{22}$ they

17. Lund, above $\mathrm{n} 7$; Boulton, above $\mathrm{n} 7$.

18. See below text above nn $28-31$.

19. On the function of codes, see eg D L Rhode "Why the ABA Bothers: A Functional Perspective on Professional Codes' (1980-81) 59 Texas LR 689; L H Newton 'Lawgiving for Professional Life: Reflections on the Place of the Professional Code' in A Flores (ed) Professional Ideals (Belmont, CA: Wadsworth Publishers, 1988); M S Frankel 'Professional Codes: Why, How and with What Impact' (1989) 8 Journal of Business Ethics 109; N Moore 'The Usefulness of Ethical Codes' (1989) Annual Survey of American Law 7; F C Zacharias 'Specificity in Professional Responsibility Codes: Theory, Practice, and the Paradigm of Prosecutorial Ethics' (1993) 69 Notre Dame LR 225; M Coady and C Bloch (eds) Codes of Ethics and the Professions (Carlton South: Melbourne University Press, 1996); L E de Groot-van Leeuwen and W T de Groot 'Studying Codes of Conduct: A Descriptive Framework for Comparative Research' (1998) 1 Legal Ethics 155.

20. See eg D Rueschemeyer 'Professional Autonomy and the Control of Expertise' in R Dingwall and P Lewis (eds) The Sociology of the Professions: Lawyers, Doctors and Others (London: MacMillan, 1983) p 41; C Menkel-Meadow 'Portia Redux: Another Look at Gender, Feminism and Legal Ethics' in Parker and Sampford (eds), above n 8, pp 39--40; A A Paterson 'Professionalism and the Legal Services Market' (1996) 3 International Journal of the Legal Profession 137.

21. See H W Arthurs 'Climbing Kilimanjaro: Ethics for Postmodern Professionals' (1993) 6 Westminster Affairs 3 and 'The Dead Parrot: Does Professional Self-Regulation Exhibit Vital Signs?' (1995) 33 Alberta LR 800; B L Arnold and J Hagen 'Careers of Misconduct: The Structure of Professional Deviance among Lawyers' (1992) 57 American Sociological Review 771.

22. See eg P Shuchman 'Ethics and Legal Ethics: The Propriety of the Canons as a Group Moral Code' (1968) 37 Geo Wash LR 244; T Schneyer 'Professionalism as Politics: The Making of a Modern Legal Ethics Code' in R Nelson, D Trubek and R Solomon (eds) Lawyers' Ideals/Lawyers' Practice (Ithaca: Cornell University Press, 1992); D Sugarman 'Bourgeois Collectivism, Professional Power and the Boundaries of the State: The Private and Public Life of the Law Society, 1825-1914' (1996) 3 International Journal of the Legal Profession 81. 
are the closest one comes to a collective statement of the ideals, values and behavioural standards to which professions are committed..$^{23}$ As such, codes inform the public of what they can expect from professions, whilst also allowing professionals to resist client demands for unethical action. From an internal perspective, codes may provide a focus for stimulating intra-professional debate over ethical issues. They may also resolve 'co-ordination problems' ${ }^{24}$ by spreading the sacrifice of self-interest involved in upholding ethical standards between all professional members or, less commendably, be used to promote the interests of some professionals over others or protect the profession from external competition.

However, perhaps the most important code function, and the one which underpins many others, is to ensure ethical behaviour. This function can be achieved directly, depending on the particular regulatory strategy adopted, either by deterring behaviour deemed unethical or otherwise unprofessional, or more positively by encouraging ethical behaviour. Indirectly, codes may perform an educative function by inculcating ethical norms both at the start of and throughout a professional's career.

This function is, of course, not unique to professional codes. Lawyers are still subject to external legal controls, all intending practitioners must take professional responsibility courses, and informal socialisation within the profession will always occur. Nevertheless, the codes can now be seen as the central means of inculcating and enforcing ethical behaviour. Given that they are partly based on relevant statutory and common law norms, the codes constitute separate, enforceable sets of rules and principles ${ }^{25}$ and act as a readily accessible guide to professional behaviour norms. Consequently, they tend to constitute the (in many cases, exclusive) focus of the brief ethical instruction in the professional stage of legal education which represents most students only exposure to legal ethics. Moreover, the fact that breaches of the codes can lead to disciplinary action means that lawyers may ignore them at their peril.

These reasons suggest that the codes have considerable potential to influence lawyer behaviour and therefore deserve a central place in discussions of professional legal ethics. However, I shall argue that their impact is likely to be limited if individual lawyers are not committed to acting ethically. This requires possession of the sort of character which regards doing the right moral thing (whatever that might involve) as important and worthy of pursuit notwithstanding the many disincentives and counter-pressures thrown up in contemporary legal practice. If developed, such moral character represents the most effective and potentially long-term means of improving lawyer morality. Nevertheless, while there are undoubtedly myriad factors affecting lawyers' character development, I will seek to show that, depending on their form, codes have a role to play in helping to develop and sustain moral character.

23. A Woolley 'Integrity in Zealousness: Comparing the Standard Conceptions of the Canadian and American Lawyer' (1996) 1 Canadian Journal of Law and Jurisprudence 61 at 71.

24. J Lichtenberg 'What are Codes of Ethics?' in Coady and Bloch (eds), above n 19, p 21ff.

25. Kenyon-Brown v Desmond Banks and Co (unreported, 1998), Lawtel transcript no C8600213. 


\section{Legal Studies}

Here one can distinguish between two ideal-types of codes. ${ }^{26}$ At one extreme, 'aspirational codes' eschew detailed ethical guidance for statements of broad principles couched in the language of moral suasion. If intended for anything more than window dressing, such codes at best guide rather than direct moral behaviour. Moreover, aspirational codes set high standards, but do not reinforce these with disciplinary sanctions. At the other extreme are lengthy codes specifying professional duties which attempt to deal with all potential ethical and conduct issues in a detailed fashion. Although specific rules are occasionally justified on consequential grounds, ${ }^{27}$ they usually follow a deontological, and hence legalistic, ethical model in laying down rules which apply in an all-or-nothing, categorical manner without reference to the particular context or consequences of the prohibited or required behaviour. Moreover, the rules tend to lay down minimalist behaviour standards, and to focus on prohibition rather than positive duties. Since rule breaches are punished by sanctions, such codes are usually called 'disciplinary codes'.

Given that all British codes are reinforced by disciplinary sanctions, none fits the pure aspirational model. However, the Faculty of Advocates' Guide to the Professional Conduct of Advocates ${ }^{28}$ is drafted in largely aspirational language and runs to a mere 33 pages. Even shorter is the Code of Conduct for Scottish Solicitors, ${ }^{29}$ which simply reproduces the aspirational code drafted by the Comité Consultatif des Barreaux Européens (though the Solicitors Professional $H_{\text {Handbook }}{ }^{30}$ collects, but does not systematise, more detailed norms contained in codes for criminal work and solicitor-advocates and in the various practice rules, regulations and guidelines promulgated as secondary legislation). The Code of Conduct of the Bar of England and Wales ${ }^{31}$ does contain detailed rules, but these generally concern issues such as the system of pupillage, the running of chambers, and work in law centres, rather than ethically contentious issues which tend to be governed by general, and sometimes rather vague, principles.

By contrast, notwithstanding numerous vague principles and even references to virtues like independence and integrity, the English and Welsh Law Society's Guide to the Professional Conduct of Solicitors, ${ }^{32}$ reflects a noticeable preference for detailed norms. Consequently, its systematised collection of various practice rules, regulations and guidelines, relevant legislation and codes for specific practice areas exceed 750 densely packed pages. Interestingly, the Guide's status as a disciplinary code is currently threatened by proposals to 'simplify the rules and make them less burdensome for the benefit of clients and practitioners', and to organise them into a hierarchy of core duties, detailed rules and non-mandatory guidance. ${ }^{33}$

26. See eg C Sampford with C Parker 'Legal Regulation, Ethical Standard-Setting, and Institutional Design' in Parker and Sampford (eds), above n 8, p 14ff; Nicolson and Webb, above $\mathrm{n} 1, \mathrm{p} 97 \mathrm{ff}$.

27. As in the case of confidentiality: see eg Nicolson and Webb, above n 1, pp 258-259.

28. Edinburgh: Faculty of Advocates, 1988.

29. See Solicitors Professional Handbook 2004 (Edinburgh: W Green/Sweet \& Maxwell, 2004).

30. Solicitors Professional Handbook 2004, above n 29.

31. London: General Council of the Bar, 2000, as amended.

32. London: The Law Society, 8th edn, 1999.

33. 'Rules for the Twenty-First Century: Final Consultation on a New Set of Professional Conduct Rules' (London: The Law Society, 2004). 
If, as I claim, a code should be designed with the promotion of moral character in mind, then these proposals represent a step in the right direction. However, in order best to support character development, I will argue that they need to go further and require lawyers to resolve ethical dilemmas in the light of relevant contextual factors. To some extent, this argument echoes that of others, most recently Hutchinson. ${ }^{34}$ However, he sees such judgment as operating outside the codes rather being incorporated into its design. Conversely, such incorporation has been championed by Simon, ${ }^{35}$ and by Webb and myself, ${ }^{36}$ but without being linked specifically to the need to foster and sustain moral character. This article seeks to bring together the arguments for character and contextuality, whilst also sketching the contours of a contextual code in more detail than Simon.

It should be noted, however, that I am not arguing that a contextual code provides the only or even the best method of inculcating ethical awareness and commitment amongst lawyers through character development. It is possible that reforms relating to legal education, professional role morality, the adversarial system and various other aspects of legal practice, such as its increasing commercialisation, bureaucratisation and specialisation, might have an even greater impact on attempts to foster and sustain lawyers' moral character. ${ }^{37}$ However, since the professional codes appear to be here to stay, their limitations and optimum form for promoting moral behaviour also require serious consideration.

\section{WHAT IS WRONG WITH CODES?}

My starting point for such consideration is the various philosophical and psychological problems with seeing morality in terms of obedience to rules. This approach flows from a philosophical tradition that has dominated ethics since the Enlightenment. It is often called the deontic tradition because it sees morality in terms of duties. ${ }^{38}$ Deontic ethics is most obviously associated with deontologists like Kant and his successors (Rawls, Gewirth etc), but it is also found in many religions, as exemplified by the Bible's ten commandments, and even in utilitarianism. What they share is an emphasis on universally applicable principles or rules imposing behavioural duties. These duties may be specific and categorical (do not lie) or they may be much more general

34. A C Hutchinson Legal Ethics and Professional Responsibility (Toronto: Irwin Law, 1999) (extracted in 'Legal Ethics for a Fragmented Society: Between Professional and Personal' (1998) 5 International Journal of the Legal Profession 176 and 'Taking it Personally: Legal Ethics and Client Selection' (1998) 1 Legal Ethics 168). See also eg Webb, above n 14; D Luban 'Epistemology and Moral Education' (1983) 33 JLE 636; H L Feldman 'Codes and Virtues: Can Good Lawyers Be Good Ethical Deliberators?' (1996) 69 Southern Calif LR 885; S G Kupfer 'Authentic Legal Practices' (1996) 10 Georgetown Journal of Legal Ethics 33.

35. W H Simon The Practice of Justice: A Theory of Lawyers' Ethics (Cambridge, Mass: Harvard University Press, 1998) pp 9-11, 69-74, chs 6-7.

36. Above n 1, pp 115-116, 242-247, 263-275, 280-286.

37. As regards these factors, see below nn 76, 79-80, 90-91, 128-132 and associated text.

38. Deon being the ancient Greek for duty. 


\section{Legal Studies}

(always do whatever maximises utility in any given situation). For some, intellectual reason, human intuition or natural sympathy were thought to enable one to know what one's duties required, and that this would somehow motivate moral behaviour, but more commonly it was thought that moral duties needed to be identified by the 'experts' (philosophers, politicians, religious leaders), laid down in ethical, legal and religious codes, and reinforced by threats of punishment. ${ }^{39}$

Reducing ethics to obeying externally set duties and codes is, however, increasingly seen as an inferior form of morality. Thus, for example, following a pure form of Kantianism, ${ }^{40}$ the psychologist Kohlberg regards the highest stage of moral development as involving individuals formulating their own moral principles (though he nevertheless believes that these apply universally). ${ }^{41}$ More radically, postmodernists like Bauman argue that codes are the antithesis of morality and that morality ends where ethical codes begin. ${ }^{42}$ Morality involves recognising the Other's unspoken and unconditional demand, which, because it is unlimited in scope and ambiguous as to content, cannot be reduced to formulae and rules. Indeed, Bauman argues that the 'greater the moral responsibility, the dimmer is the hope of its normative regulation'. ${ }^{43}$ Morality is thus marked by personal choice and anxiety, both of which are extinguished by codes.

While there is much that is inspirational in these accounts of ethics, one need not go this far to realise that relying solely on codes and duties to ensure lawyer ethics is inadequate. Instead, one can begin with the psychology of moral behaviour. Following Rest, it is now accepted that moral behaviour (whatever its content) involves four ${ }^{44}$ components: sensitivity, judgment,

39. See Z Bauman Postmodern Ethics (Oxford: Blackwell, 1993), esp Introduction and chs 1 and 3; A J Dawson 'Professional Codes of Practice and Ethical Conduct' (1994) 11 Journal of Applied Philosophy 146.

40. Known as act-deontology: see eg W K Frankena Ethics (Englewood, Cliffs, NJ: Prentice-Hall, 1963) pp 21-23; T L Beauchamp Philosophical Ethics: An Introduction to Moral Philosophy (New York: McGraw-Hill, 1982) pp 115-116.

41. See eg L Kohlberg 'Moral Stages and Moralization: The Cognitive-Developmental Approach' in T Lickone (ed) Moral Development and Behaviour (New York: Holt, Rinerhart and Winston, 1976), Essays on Moral Development, Vol 1: The Philosophy of Moral Development (New York: Harper and Row, 1981) and Essays on Moral Development, Vol 2: The Psychology of Moral Development (New York: Harper and Row, 1984); L Kohlberg, C Levine and A Hewer Moral Stages: A Current Formulation and a Response to Critics (London: Karger, 1983).

42. See Bauman, above $\mathrm{n} 39$, Life in Fragments: Essays in Postmodern Morality (Oxford: Blackwell, 1995), esp ch 1 and 'What Prospects of Morality in Times of Uncertainty?' (1998) 15 Theory Culture and Society 11. See also Dawson, above n 39, at 153; S Salbu 'Law and Conformity, Ethics and Conflict: The Trouble with Law-Based Conceptions of Ethics' (1992) 68 Ind LJ 101.

43. 'What Prospects of Morality', above n 39, p 20 (emphasis removed).

44. But see L J Duckett and M B Ryden 'Education for Ethical Nursing Practice' in J Rest and D Narvaez (eds) Moral Development in the Professions: Psychology and Applied Ethics (Hillsdale, NJ: Lawrence Erlbaum Associates, 1994) p 61, who argue that 'implementation' involves a fifth, albeit interpersonal rather than purely psychological, component. 
motivation and courage. ${ }^{45}$ First, moral sensitivity enables individuals to recognise moral problems when they arise. This requires both cognitive and affective psychological capacities, since awareness of a moral problem may stem from empathy or guilt rather than intellectual categorisation. Secondly, moral judgment enables individuals to identify the salient features of issues, and to select and justify appropriate responses. Here the intellectual capacities of knowledge and reasoning may dominate, as when individuals first evaluate and select from competing ethical theories or duties and then decide what behaviour they require. But again, as feminists, postmodernists and a host of earlier ethicists argue, the response to moral issues might equally be an emotional one. ${ }^{46}$

These two components, however, only take us so far towards moral behaviour. Empirical research repeatedly confirms that knowing what is morally right is only weakly linked to doing what is right. ${ }^{47}$ Acting morally requires two additional components. Moral motivation ensures that individuals want to put into effect the moral solution selected and elevate it over competing considerations like self-interest or institutional values. Without this component, individuals might know what morality requires but not in fact care. Here it is moral feelings and character dispositions which are important rather than cognition. But even if they care, individuals require the moral courage to be able to convert ethical thought and concern into ethical action by resisting temptations to compromise moral standards. Crucial here are the personal virtues of moral fibre, steadfastness, perseverance and backbone, or what psychologists call ego-strength.

This psychological model of moral behaviour reveals a number of problems with deontic ethics in general and the reliance on ethical codes in particular. One is that the common emphasis in deontic ethics on rationality, and the intellectual understanding of duties and their application to fact situations, leaves little space for the sort of affective psychological capacities that sensitise people to moral situations, help them choose appropriate behaviour and motivate moral behaviour. ${ }^{48}$ Emotional faculties also influence whether moral decisions are implemented in a 'rational, but cool, distant or autocratic manner

45. The chapters in Rest and Narvaez (eds), above $\mathrm{n} 44$, esp ch 1; J Rest 'The Major Components of Morality' in W Kurtines and J Gewirtz (eds) Morality, Moral Behaviour and Moral Development (New York: Wiley, 1984); D Narvaez and J Rest 'The Four Components of Acting Morally' in W M Kurtines and J L Gewirtz (eds) Moral Development: An Introduction (Boston: Allyn and Bacon, 1995). NB: whereas the above refer to 'moral character' as the fourth component, I use the term 'moral courage', because of my argument that developed moral character involves all four components.

46. See eg Nicolson and Webb, above $\mathrm{n}$ 1, pp 34-38, and 46-49 regarding feminism and postmodernism; and J C Tronto Moral Boundaries: A Political Argument for an Ethic of Care (London: Routledge, 1993) regarding Scottish Enlightenment philosophers. See also S G Clarke and E Simpson 'Introduction: The Primacy of Moral Practice' in S G Clarke and E Simpson (eds) Anti-Theory in Ethics and Moral Conservatism (New York: State University of New York, 1989).

47. See J Rest 'Background: Theory And Research' in Rest and Narvaez (eds), above n 44, pp 21-22, and 'Can Ethics be Taught in Professional Schools? The Psychological Research' (1988) 1 Ethics Easier Said Than Done 22.

48. Feldman, above n 34, esp at 904-908. 


\section{Legal Studies}

... [or] ... in a manner that illustrates interpersonal warmth, empathy, compassion, and connectedness'.49

A second and more serious problem is that codes and duties are highly unlikely on their own to equip lawyers to identify and resolve all potential ethical problems arising in legal practice. ${ }^{50}$ Attempts by disciplinary codes to deal conclusively with all possible moral problems are likely to be frustrated by limited foresight, and the rapidly changing nature of legal practice and its social context. Moreover, as the legal profession's current rules exemplify, ${ }^{51}$ codes often contain conflicting duties but no means to resolve such conflicts. One solution might be to provide overriding general principles, ${ }^{52}$ but this raises the problem that afflicts aspirational codes, namely that general principles are usually too vague to determine their application to concrete dilemmas. In fact, given the inherent ambiguity and vagueness of language, even specific rules are open to varying interpretations. This suggests that codes always require those they govern to exercise judgment, albeit to differing degrees depending on whether they are disciplinary or aspirational..$^{53}$ Yet, as we shall see, codes alone are not sufficient to inculcate effective ethical judgment in lawyers.

The final and most important drawback to codified, duty-based ethics is that even if lawyers can identify and resolve moral problems, they still need to care about acting morally and to have the courage to do so when faced with competing pressures and temptations. Professional legal ethics discourse has little to say about moral motivation and courage. Instead, either these are just assumed to exist or it is hoped that the threat of sanctions will ensure that codes are obeyed. The effectiveness of this threat is, however, crucially dependent on the profession's ability to detect wrongdoing, often in situations where lawyer behaviour is hidden from view, ${ }^{54}$ and in a milieu where lawyers are unlikely to be willing to risk ostracisation by reporting their colleagues. ${ }^{55}$ It is also dependent on the profession possessing the resources and will to pursue and punish wrongdoers, yet the record to date ${ }^{56}$ indicates that neither commodity is in great supply. Moreover, empirical research suggests that professionals who pay attention to ethical rules solely because of threatened punishment have a weakened commitment to the mandated behaviour. ${ }^{57}$ This

49. Duckett and Ryden, above $\mathrm{n} 44, \mathrm{p} 61$.

50. See eg Dawson, above $n 39$; Feldman, above $n$ 34, at $932 \mathrm{ff}$.

51. See Nicolson and Webb, above $n 1$, ch 8 .

52. Another might be to utilise the codes' 'spirit' (F Silverman Handbook of Professional Conduct for Solicitors (London: Butterworths, 1989) p 69; Inns of Court School of Law Professional Conduct (London: Blackstone, 2nd edn, 1997) p 2), but whether a spirit exists and is identifiable by individual practitioners is highly dubious: Sheinman, above n 11 , at 143 .

53. No doubt, lawyers could (and in fact do) seek authoritative interpretations from their professional bodies. However, lawyers might not care sufficiently about acting morally to consult them, some moral issues might require immediate resolution, whereas the approach of always seeking advice in cases of ambiguous aspirational norms would be impractical.

54. O'Dair, above $\mathrm{n} 9$, p 5.

55. Rhode, above n 19 , at 709 .

56. Abel, above n 6, pp 134-135 and 252-253; M Zander 'Only the talk is tough' Gazette 95, 2 December 1998, p 46; The Times, • May 1998, p 9.

57. M M Coady 'The Moral Domain of Professionals' in Coady and Bloch (eds), above n $19, \mathrm{p} 49$. 
is particularly problematic in the case of lawyers given that their skills in finding ways around inconvenient rules meant that they might not regard code rules as greatly limiting their freedom to act unethically.

Duty-based codes of ethics thus fail to address much of what is psychologically required for moral behaviour. The increasingly common response is a call for a return to virtue or aretaic ${ }^{58}$ ethics, which can be traced back to the Greeks, particularly Aristotle. Gradually overtaken by the dutybased Judao-Christian approach to morality, virtue ethics was eclipsed by deontic ethics following the Enlightenment, ${ }^{59}$ only to be revived recently in response to the perceived failures of deontic ethics. ${ }^{60}$

By contrast to deontic ethics, virtue ethics emphasises 'being' rather than 'doing'; character rather than action. ${ }^{61}$ Given that we generally judge character from someone's behaviour, ${ }^{62}$ action is not ignored altogether. Nevertheless, morality is seen largely as a question of a person's overall moral worth and in particular their possession of moral virtues, namely fixed character traits, dispositions or habits of belief, perception, feeling and behaviour which are regarded as morally right or commendable. Virtue ethics focuses on what counts as moral goodness and the virtuous life, and how people can make themselves morally better through developing moral virtues. It recognises that individuals are not born with developed virtues, nor with the 'practical wisdom' which enables them to see how to act in practical situations and allows their natural propensity to act morally to flower into virtue. Instead, virtue and practical wisdom are gradually developed through actual engagement with moral issues. By emulating others, by trial and error, by instruction from authoritative others, and by experiencing the appropriate satisfaction or regret at the outcome of one's actions, moral dispositions gradually develop to the point that appropriate moral behaviour, beliefs and feelings become part of the individual's essential character. ${ }^{63}$ As McDowell puts it: '[o]ccasion by

58. From the Greek 'arete' meaning excellence, referring here to excellences of moral character (ie virtues).

59. But see J Haldane 'Medieval and Renaissance Ethics' in P Singer (ed) A Companion to Ethics (London: Blackwell, 1991) pp 143-144 regarding the continuing legacy of Aristotle and Aquinas' merger of his ideas with Catholic doctrine.

60. See eg G E M Anscombe 'Modern Moral Philosophy' (1958) 33 Philosophy 1; A MacIntyre After Virtue: A Study in Moral Theory (London: Duckworth, 2nd edn, 1985); B Williams Ethics and the Limits of Philosophy (London: Fontana Press, 1985).

61. The following account draws on Beauchamp, above $\mathrm{n} 40$, ch 5; Dawson, above n 39; Feldman, above n 34; Frankena, above n 40, ch 4; A Flores 'Introduction: What Kind of Person Should a Professional Be' in Flores, above n 19; G Pence 'Recent Work on Virtues' (1984) 21 American Philosophical Quarterly 281 and 'Virtue theory' in Singer, above n 59; R Hursthouse On Virtue Ethics (Oxford: Oxford University Press, 1999). See also J J Kupperman Character (New York: Oxford University Press, 1991) and 'Character and Ethical Theory' (1988) 13 Midwest Studies in Philosophy 115, regarding what he describes as character, rather than virtue, ethics.

62. Cf O O'Neill Toward Justice and Virtue: A Constructive Account of Practical Reasoning (Oxford: Blackwell, 1998) p 72.

63. See Aristotle The Nicomachean Ethics (Amherst, NY: Prometheus Books, 1987) esp Bk II, ch I and Bk VI, ch XIII; and see further Luban, above n 34; D Carr Educating the Virtues: An Essay on the Philosophical Psychology of Moral Development and Education (London: Routledge, 1991). 


\section{Legal Studies}

occasion, one knows what to do, if one does, not by applying universal principles but by being a certain kind of person: one who sees situations in a certain distinctive way. ${ }^{64}$

If properly developed, and not simply constituted by unthinking habits, prejudices or other harmful beliefs, moral character can be said to equip individuals with all four psychological components of morality. Unlike traditional deontic ethics, ${ }^{65}$ virtue ethics concentrates on ensuring, not just the ability to recognise moral problems and to choose the right response, but crucially also the motivation and courage to carry through this choice. Moreover, where virtue is developed as a way of life, moral behaviour is far more likely than if individuals have to rely on any existing moral duties to persuade them to take morality seriously. For example, those whom we regard as moral 'saints' - Gandhi, Mother Teresa, Oskar Schindler, for example - were motivated by deep-seated and spontaneous feelings of compassion, and empathy - by 'habits of the heart' - rather than pious adherence to duty.

However, in addition to refreshing those components of moral behaviour that deontic ethics cannot reach, virtue ethics is said to have other advantages. One is that there are many aspects of good character, such as displaying personal integrity, the appropriate emotional response to others, or commitment to persons, groups or political causes, which are relevant to morality, but which traditionally have been omitted from deontic ethics and even now cannot be easily squeezed into ethical codes and moral duties. Similarly, virtue ethics stress that, even when particular conduct is considered appropriate, one may and in many cases should - feel remorse at having to override competing moral considerations. This in turn may motivate a more sensitive and caring implementation of the ethical decision.

Another advantage of going beyond deontic ethics is that the mere fact that people obey moral obligations tells us little about their morality. They might, for instance, obey out of self-interest. Virtue ethicists argue against Kant that even obedience motivated by a sense of duty is less morally praiseworthy than virtuous behaviour stemming from dispositions, traits and sentiments which lie at a deep level of psychological motivation, ${ }^{66}$ and which lead to immoral conduct being dismissed out of hand or not even entering the mind.

Finally, it is arguable that virtue ethics deals even better with the two components of moral behaviour that deontic ethics does cover. This is because virtuous dispositions involve ways of feeling as well as thinking and, according to moral psychologists, emotions are as - if not more - important to morality than the intellect. Unlike rational thought, sentiments like affection and empathy play a role in all four components of moral behaviour: even moral judgment, its most rational component. Judgment, it is argued, does not only involve rationally working out which duty best fits a moral dilemma and how

64. J McDowell 'Virtue and Reason' (1979) 62 The Monist 331 at 347.

65. Contemporary deontologists and consequentialists are beginning to address many of the central aretaic concerns (McDowell, above n 64, esp at 3-4, 54), but it remains to be seen whether they can coherently incorporate them and give them the attention they deserve.

66. See eg Hursthouse, above n 61, ch 4; P Foot Virtues and Vices (Oxford: Basil Blackwell, 1978) pp 13-14. 
Making lawyers moral? Ethical codes and moral character 613

it should be applied. It also involves a 'perceptual capacity' ${ }^{67}$ which enables individuals to respond to the requirements of each unique situation by drawing upon empathy, compassion and imagination, as well as their past experiences and entire world-view. ${ }^{68}$ This is essential because, even if moral codes do regulate all moral issues, they can never be sufficiently flexible or sensitive to cope with the specific nuances, particularities, and emotional aspects of each unique moral situation. Furthermore, as we have seen, codes are unlikely to regulate all relevant issues and, here, moral character acts to fill the gap.

\section{WHAT IS RIGHT WITH CODES?}

Ethical codes thus appear only partly to address the requirements for moral behaviour. This might suggest that the energy expended in drafting and enforcing code provisions would be better directed at supporting the moral character that lawyers bring with them to the job. Thus the Faculty of Advocates claims - remarkably, in its code's preface ${ }^{69}$ - that throughout the last 450 years:

'... it has never been felt necessary to produce a code of written rules with which an advocate is expected to comply. Nor has such a code become necessary now. The work of an advocate is essentially the work of an individual practitioner whose conscience, guided by the advice of his seniors, is more likely to tell him how to behave than any book of rules.'

In referring to a lawyer's 'conscience, guided by the advice of his seniors', the Faculty seems to echo the aretaic approach to ethics. However, no attempt is made to explain how lawyers come to possess the character attributes justifying this trust. The traditional suggestion was that the 'gentleman lawyer's' social background ensured that he was of the 'right stuff'. ${ }^{70}$ But even if one accepts that a white, upper middle-class upbringing generated the right moral character, the current diversity of lawyers' backgrounds ${ }^{71}$ makes this argument outdated. Moreover, if character alone guaranteed ethical standards, one might expect rigorous checks on professional entrants and unethical lawyer behaviour to be confined to a few bad apples who elude this form of quality control. Yet checks on professional entrants' moral fitness to practise are perfunctory, ${ }^{72}$ whereas

67. McDowell, above $\mathrm{n} 64$, at 333 .

68. See D Luban and M Millemann 'Good Judgment: Teaching Ethics in Dark Times' (1995) 9 Georgetown Journal of Legal Ethics 31.

69. Above $n 28$.

70. See above $n 16$.

71. See D Nicolson 'Demography, Discrimination And Diversity: Legal Ethics And Social Background' (2005) 12 International Journal of the Legal Profession (forthcoming). 72. D Rhode 'Moral Character as Professional Credential' (1985) 94 Yale LJ 411; Hutchinson, above $\mathrm{n} 34, \mathrm{p} 62$, who also notes that character assessment comes too early, in that professional entrants have not yet tested their character through actual ethical dilemmas in practice. 


\section{Legal Studies}

studies of lawyer activity ${ }^{73}$ and disciplinary proceedings ${ }^{74}$ reveal that unethical behaviour - or at least breaches of professional norms - is far from rare.

In the past, eschewing moral codes could possibly have been justified on the grounds that the collegiality of a small close-knit legal profession and the typicality of long apprenticeships ensured informal socialisation into accepted ethical norms. ${ }^{75}$ While this argument might still apply to the Faculty of Advocates, whose membership is small and centrally located, it is no longer plausible even at the English and Welsh bar, which is now relatively large, demographically diverse and geographically widely distributed - factors of course which apply even more to solicitors. In addition, the profession's increased fragmentation along economic and specialist lines means that professional socialisation will vary from one practice milieu to another and will be located in individual chambers and firms, if not smaller units within firms. ${ }^{76}$

In a slightly different vein, Philips, argues that ethical codes lower rather than raise ethical standards and are unnecessary as most moral problems can be resolved using 'first principles' ${ }^{77}$ However, the existence of universally and objectively valid moral principles is now widely questioned, and not only by postmodernists. ${ }^{78}$ And, even if such first principles do exist, Philips himself admits that they cannot indisputably solve all problems and then unwittingly confirms this by identifying the lawyer's duty to pursue client interests as the foundational principle of lawyers' ethics. Admittedly this duty, and more fundamentally the role morality of neutral partisanship, which requires lawyers to act zealously for clients irrespective of moral considerations, does have a prominent role in the codes. ${ }^{79}$ However, it is not officially accepted as the central principle of ethical practice and, if it were to be, this would be highly contentious $^{80}$ and hence unable to justify the eradication of written rules.

73. J Baldwin and M McConville Negotiated Justice: Pressures to Plead Guilty (London: Martin Robertson, 1977); G Davis Partisans and Mediators (Oxford: Clarendon Press, 1994); M McConville, J Hodgson, L Bridges and A Pavlovic Standing Accused: The Organisation and Practices of Criminal Defence Lawyers in Britain (Oxford: Clarendon Press, 1994); A Boon 'Ethics and Strategy in Personal Injury Litigation' (1995) 22 JLS 353; H Genn Hard Bargaining (Oxford: Clarendon Press, 1997); B Neale and C Smart "'Good" and "Bad" Lawyers? Struggling in the Shadow of the New Law' (1997) 19 Journal of Social Welfare \& Family Law 377; M McConville 'Plea Bargaining: Ethics and Politics' (1998) 25 JLS 562; J Griffiths-Baker Serving Two Masters (Oxford: Hart Publishing, 2002).

74. See the studies cited in above $\mathrm{n} 56$; and A Sherr and L Webley 'Legal Ethics in England and Wales' (1997) 4 International Journal of the Legal Profession 109 at 121. 75. Cf Burrage, above $\mathrm{n} 6$, at 54; Thornton, above n 16, pp 56-57.

76. See eg Burrage, above n 6, at 54; Nicolson and Webb, above n 1, ch 3, esp pp 6061; Boon and Levin, above n 9, ch 3, esp pp 89-94; A Francis 'The Business Context: Legal Ethics, the Marketplace and the Fragmentation of Legal Professionalism' (2005) 12 International Journal of the Legal Profession (forthcoming).

77. Phillips, above n 7, esp preface and ch 1 . See also the introduction to the Code of Conduct for Scottish Solicitors, above n 29.

78. See Nicolson and Webb, above n 1, pp 39-46.

79. Nicolson and Webb, above $\mathrm{n} 1$, chs 6 and 8.

80. See eg Nicolson and Webb, above n 1, chs 6-9; Boon and Levin, above n 9, esp pp 26-36; O'Dair, above n 9, esp ch 5; R Cranston 'Legal Ethics and Professional Responsibility' in Cranston, above n 8; Special Issue 'Lawyers' Duties, Adversarialism and Partisanship in UK Legal Ethics' (2004) 7 Legal Ethics 167. 
Moreover, as Paterson argues, under the intuitive, first-principle approach lawyers might become heavily embroiled in problems like conflict of interest without even realising it. ${ }^{81}$ A similar point undermines the Faculty of Advocates' faith in the ability of experienced lawyers to guide young professionals down the right moral track. Without introduction to the myriad ethical problems raised by legal practice, many legal neophytes may not get as far as seeking guidance and, even if they do, their 'seniors' might not themselves have experienced or even considered the problem raised.

In addition to these problems with abandoning ethical codes, there are three other major considerations. The first is that, whatever might be best from a theoretical perspective, ethical deregulation is a non-starter politically since the consumer and state demands for greater professional accountability and transparency which helped precipitate codification show no signs of dissipating. ${ }^{82}$

Secondly, critics of virtue ethics argue that relying on character alone to ensure moral behaviour is risky. ${ }^{83}$ This is because focusing on the totality of an individual's character may leave single acts of immorality unchallenged; because the virtues are too vague and controversial to adequately guide moral behaviour; and because virtue ethics is inherently conservative in seeing character development as tied to practices within particular communities, thus potentially leading to unthinking vicious rather than virtuous habits and dispositions. Whilst somewhat exaggerated, ${ }^{84}$ these dangers suggest that, just as duty-based ethics cannot get off the ground without moral character, so is it preferable ${ }^{85}$ for virtue ethics to be supplemented by moral principles which enable evaluation of the actions of even virtuous individuals. ${ }^{86}$

The final consideration which cautions against total ethical deregulation takes us to the heart of my argument about the interrelationship between ethical codes and moral character. Thus far I have argued that codes will underdetermine ethical behaviour unless lawyers care about and are committed to acting ethically. I will now seek to show that codes can play an important role in the development and maintenance of the moral character which ensures

81. A Paterson 'Legal Ethics: Its Nature and Place in the Curriculum' in Cranston, above n 8, p 177.

82. Cf A Crawley and C Bramall 'Professional Rules, Codes and Principles Affecting Solicitors (or What Has Professional Regulation to do with Ethics?)' in Cranston, above n 8, p 105.

83. See eg O'Neill, above n 62; T L Beauchamp and J F Childress 'Virtues and Conscientious Actions' in Flores, above $\mathrm{n} 19$.

84. Eg Hursthouse, above $\mathrm{n} 61$, ch 1 , argues that virtues are no less vague in guiding behaviour than the principle of utility or the idea of applying correct moral rules, whereas her discussion of the role of reason in virtuous action (pp 124-125) counters the idea that moral character may include unthinking prejudices.

85. But not essential: H I Dreyfus and S E Dreyfus 'What is Morality? A Phenomenological Account of the Development of Ethical Expertise' in D Rasmussen (ed) Universalism and Communitarianism (Cambridge, Mass: MIT Press, 1990) p 258. 86. See Frankena, above n 40; Beauchamp and Childress, above n 83; and O'Neill, above $\mathrm{n} 62$, who have sought to integrate the deontic and aretaic traditions. In the context of professional ethics generally and lawyers' ethics see, respectively, B Jennings 'The Regulation of Virtue: Cross-Currents in Professional Ethics' (1991) 10 Journal of Business Ethics 561; Nicolson, above n 14. 


\section{Legal Studies}

not only these two components of moral psychology but also enhanced moral sensitivity and judgment.

As we have seen, virtue ethics holds, and psychological research confirms, ${ }^{87}$ that we are not born with fully formed moral characters. Instead, morality develops over time and, although it may slow and stagnate, moral development may also continue throughout adulthood, especially for those who enter tertiary education, and who take ethics courses. ${ }^{88}$ Yet, whatever professional entrants' existing state of moral development, they will not have been exposed to the type of ethical issues raised by legal practice and the moral considerations relevant to their resolution. Accordingly, they will have not begun to develop the intuitive and spontaneous responses to professional moral problems, the nuanced moral judgment, and the motivational and behavioural dispositions needed in legal practice. In other words, while legal neophytes may possess a personal moral character they have yet to develop a professional moral character.

It is in helping to develop and sustain such 'professional moral character' that codes can play an important role. Aristotle ${ }^{89}$ himself acknowledged that the development of moral character starts with the application of rules before reaching the point where stable motivational and behavioural dispositions are in place. Through exposure to the codes, students can learn what issues previous generations have identified as relevant to legal practice and what solutions they regard as justified. This experience needs to extend beyond knowing the rules to evaluating their appropriateness and underlying justifications. And, if morality is going to become integral to a lawyer's professional character, law students and the newly qualified need to practise applying the rules in roleplaying ${ }^{90}$ and preferably also clinical work. ${ }^{91}$ The rules can also provide the

87. See Kupperman (1991), above n 61, ch 3 .

88. See eg Kohlberg, above $n$ 41; the essays in Rest and Narvaez (eds), above n 44; Rest, above n 45; J Rest and D Narvaez 'The College Experience and Moral Development' in W M Kurtines and J L Gewirtz Handbook of Moral Behaviour and Development (Hillsdale, NJ: L Erlbaum, 1991).

89. Above n 63, esp Bk X, ch 10. See also Dreyfus and Dreyfus, above n 85; R S Peters 'Moral Development and Moral Learning' (1974) 58 The Monist 541.

90. See generally the essays in Rest and Narvaez (eds), above n 44, esp that by Sprinthall; D A J Richards 'Moral Theory, the Developmental Psychology of Ethical Autonomy and Professionalism' (1981) 31 JLE 359; and in relation to legal ethics education, Paterson, above $\mathrm{n} 81$.

91. See generally N Redlich 'The Moral Value of Clinical Legal Education: A Reply' (1983) 33 JLE 613; M Jewell 'Teaching Law Ethically: Is It Possible?' (1984) 8 Dal LJ 474; S Hartwell 'Moral Development, Ethical Conduct and Clinical Education' (1990) 35 New York Law School Law Review 131; I Johnstone and M P Treuthart 'Doing the Right Thing: An Overview of Teaching Professional Responsibility' (1991) 41 JLE 75; $\mathrm{J}$ Webb 'Conduct, Ethics and Experience in Vocational Legal Education: Opportunities Missed' in Economides (ed), above n 8; A Evans 'The Values Priority in Quality Legal Education: Developing a Values/Skills Link through Clinical Experience' (1998) 32 Law Teacher 274; and more specifically in relation to character formation, Luban, above n 34; Luban and Millemann, above n 68; R Condlin 'The Moral Failure of Clinical Legal Education' in D Luban (ed) The Good Lawyer: Lawyer's Roles and Lawyer's Ethics (Totowa, NJ: Rowman and Allanheld, 1983); D Nicolson 'Making Lawyers Moral? Moral Character and Ethical Education', paper presented to the First International Legal Ethics Conference, University of Exeter, July 2004. 
focus for a lawyer's day-to-day engagement with ethical issues and professionwide ethical debates conducted by professional bodies and perhaps also in 'ethical circles' ${ }^{92}$ established to keep moral issues at the forefront of lawyers' minds, thereby contributing to continuing character development. ${ }^{93}$

\section{WHAT IS THE RIGHT TYPE OF CODE?}

This programme for character development is obviously highly dependent on legal ethics teaching becoming far more sophisticated and prominent in legal education than at present. However, it is also dependent on the design of the professional codes. Depending on their form, codes can either help inculcate and sustain such character development, or they can undermine it. The important question is which, if either, ideal-type is best suited to this task.

The clear trend, both generally ${ }^{94}$ and in the British legal profession has been towards disciplinary codes. Their supporters ${ }^{95}$ can point to the fact that, compared to aspirational codes, detailed and highly specific duties, which apply in an absolute and non-contextual fashion, define more clearly the terms of the alleged social contract between profession and community and enable closer regulatory control, thus avoiding the problems of a deregulated legal profession raised above.

Of course, as we have seen, no code will be totally clear in its requirements. However, disciplinary codes have various unique drawbacks. ${ }^{96}$ Thus the attempt to regulate all aspects of particular issues with specific rules might well lead to individual professionals and disciplinary bodies regarding issues inadvertently overlooked as not subject to ethical considerations. Disciplinary codes also suffer from being less knowable by their subjects. One reason is that detailed regulation of all contemplated ethical issues is likely to lead to dense documents, especially if the codes tailor regulation to the different environments of an increasingly specialised and fragmented profession. Another reason is that highly specific solutions to problems may quickly become outdated in a rapidly changing world, thus requiring constant revision, but if this occurs, lawyers will find it difficult to keep abreast with constant changes. Indeed, they may even become disillusioned with their professional bodies' ability authoritatively to resolve ethical problems and give up on the rules altogether.

Another set of disadvantages flows from the way in which disciplinary codes resolve moral issues. Categorical rules prevent sufficient attention being given to the context of moral dilemmas, the specific needs of those involved, and the consequences of particular solutions. Furthermore, the tendency of disciplinary

92. See Sampford and Parker, above $\mathrm{n} 8, \mathrm{p} 17$.

93. Hutchinson, above n 34, esp p 15; Kupfer, above n 34 .

94. See Moore, above n 19, at 15; Zacharias, above n 19, at 223.

95. See eg Lichtenberg, above $n$ 24; Cranston, above n 8, pp 5-6; Paterson, above n 81, pp 176-177 and 'Legal Ethics in Scotland' (1997) 4 International Journal of the Legal Profession 25 at 37; D Webb 'Book Review' (2000) 3 Legal Ethics 90 at 91.

96. See eg Feldman, above n 34; Hutchinson, above n 34; Zacharias, above n 19; Salbu, above n 42; R E Loder 'Tighter Rules of Professional Conduct: Saltwater for Thirst?' (1987) 1 Georgetown Journal of Legal Ethics 311. 


\section{Legal Studies}

codes to set lowest common denominator standards is unlikely to assuage public demands for an ethical profession. Without more aspirational ideals, ethical behaviour is likely to sink to the bare minimum required, especially if lawyers think that supererogation will place them at a competitive disadvantage. ${ }^{97}$ Given that minimalist duties are easily satisfied without much self-sacrifice, they undermine suggestions that ethical behaviour is central to professional status. And where sacrifice is expected, it will not necessarily be evenly spread throughout the profession. The more detailed a code, the less likely are its rules to reflect a consensus ${ }^{98}$ and hence the greater the scope for professional elites to draft rules reflecting their own interests. ${ }^{99}$ This in itself may make highly detailed codes unethical.

But even where professional rule-makers strive for neutrality, providing categorical answers to specific ethical dilemmas increases the chances of such answers being categorically 'wrong'. And where such 'wrong' solutions are reinforced by sanctions, lawyers are faced with either feeling guilty about their behaviour or switching off moral conscience in favour of unthinking rule adherence. As many have argued in relation to the lawyer's role morality of neutral partisanship, ${ }^{100}$ neither response to conflicts between professional and personal morality is calculated to promote an individual lawyer's psychological health or a well-adjusted profession.

However, given that it makes life more comfortable, lawyers are more likely to opt for shutting down their moral faculties. ${ }^{101}$ For those who see moral character as the best route to ethical behaviour, it is this response which represents disciplinary codes' most serious defect. Reducing ethics to adherence to detailed rules is likely to replace individual ethical decision-making with 'mindless conformity to the rules', ${ }^{102}$ especially as such rules suggest that all possible ethical dilemmas have been considered by the experts. This in turn is likely to encourage technocratic and legalistic modes of ethical reasoning, and to discourage lawyers from constantly looking to their own consciences and moral insights, and from questioning the law's justice and morality. Faced with a thicket of detailed rules, lawyers may fail to see 'the ethical forest for the lawlike trees'. As Hutchinson goes on to argue, 'weighed down with discrete and detailed directives on this or that matter, there is little to counsel the floundering

97. D Luban 'Calming the Hearse Horse: A Philosophical Research Program for Legal Ethics' (1981) 40 MdLR 451 at 460-461.

98. Though, paradoxically, the greater such a consensus, the less the rules are needed. 99. See above $n 22$.

100. G J Postema 'Moral Responsibility in Professional Ethics' (1980) 55 NYULR 63 and 'Self-Image, Integrity and Professional Responsibility' in Luban (ed) (1983), above n 91; A Eshete 'Does a Lawyer's Character Matter?' in Luban (ed) (1983), above n 91; B Williams 'Professional Morality and its Dispositions' in Luban (ed) (1983), above n 91; J J Flynn 'Professional Ethics and the Lawyer's Duty to Self' (1976) 3 Washington University Law Quarterly 429; D S Kleinberger 'Wanted: An Ethos of Personal Responsibility - Why Codes of Ethics and Schools of Law Don't Make for Ethical Lawyers' (1989) 21 Connecticut LR 365.

101. Cf R Wasserstrom 'Lawyers as Professionals: Some Moral Issues' (1975) 5 Human Rights 1 at 9 and 'Roles and Morality' in Luban (ed) (1983), above n 91, pp 29-30; W H Simon 'The Ideology of Advocacy: Procedural Justice and Professional Ethics' (1978) 29 Wis LR 103.

102. Salbu, above $\mathrm{n} 42$, at 166. 
or jaded lawyer in establishing an overall and professional modus vivendi' ${ }^{103}$ In other words, even if lawyers do possess a developed personal moral character, disciplinary codes hamper the development of professional moral character.

In fact, however, such codes may actually undermine lawyers' already existing moral character. This is because they may encourage them to reduce ethics to a matter of risk analysis and risk management, in which they make 'good guesses as to the level of malpractice at which they should operate in any given situation' ${ }^{104}$ and use their legal skills to avoid disciplinary sanctions when they miscalculate. This strategy of 'creative compliance', ${ }^{105}$ especially when combined with adherence to the role morality of neutral partisanship, may lead to cynicism and indifference to ethical considerations, which in turn may inhibit the development of professional moral character or even alter an underlying personal moral character. In this way, detailed codes may weaken those components of moral psychology that the limitations of all ethical codes make so important to ensuring moral behaviour.

Accordingly, if it is accepted that moral character is essential to ethical behaviour and that codes can help develop and sustain character, aspirational codes appear to be better suited to this task. The fact that they leave discretion to individual professionals has several advantages in relation to character development. By encouraging law students to explore alternative solutions to moral problems and their justifications, and by requiring practising lawyers (and law clinic students) to exercise judgment in real-life dilemmas, aspirational codes require regular exercise of the individual's 'moral muscles'. This should act to sustain personal, and foster professional, moral character, particularly if supported by 'moral mentors' in law schools, law clinics, and practice settings. Moreover, the lack of categorical answers allows prospective and practising lawyers to learn through trial and error, and particularly from feeling regret or remorse when chosen solutions to ethical issues turn out to be inappropriate. This is arguably one of the surest ways for developing fixed dispositions towards virtue.

An aspirational code's inclusion of professional ideals (such as upholding justice and giving legal voice to the weak, unpopular etc) and virtues (like trustworthiness, integrity, and moral courage) could also have a positive effect on moral character. Instead of requiring minimal behavioural standards, aspirational norms may inspire lawyers to strive to be as moral as they can be and, since 'it is one property of an aspiration that we properly feel ashamed of ourselves for not living up to it', ${ }^{106}$ keep alive a lawyer's moral conscience.

More generally, an aspirational code's lack of categorical solutions to specific issues is more likely than one with fixed solutions to foster ongoing profession-wide debates about the appropriate use of a lawyer's ethical discretion. Such debates could play an important role in the 'constructed community of professional norms ${ }^{107}$ and in fostering a shared sense of legal

103. Above n 34, p 182.

104. Practitioner quoted in $\bullet \cdots . \bullet$ Hazard, Ethics in the Practice of Law (New Haven: Yale University Press, 1978) p 153. See also Phillips, above n 7, pp 12 and 129.

105. See D McBarnet and C Whelan 'The Elusive Spirit of the Law: Formalism and the Struggle for Legal Control' (1991) 54 MLR 848.

106. Luban and Millemann, above $n$ 68, at 50.

107. Kupfer, above n 34, at 63 . 


\section{Legal Studies}

professionalism, understood as 'an idealised way of being' that includes commitment 'to using professional skills and knowledge, in morally acceptable ways, for the benefit of society'. ${ }^{108}$ According to Flores, 'reference to virtues such as honesty and integrity, and ideals such as truth and justice, deepens in significant ways our understanding of what it means to be a professional, and ... how professionalism must imply something more than rule-governed behaviour'. ${ }^{109}$

Aspirational codes therefore have distinct advantages over disciplinary codes. Yet we have also seen that their lack of clear direction means that professional regulators cannot argue that lawyers will act in particular ways and hence persuade the public that their interests are being protected. This is particularly so because the need for fair warning through clear norms counsels against aspirational codes being reinforced by disciplinary sanctions. Where lawyers do not already have the moral character necessary to ensure moral behaviour, the lack of sanctions may result in the codes being ignored. Moreover, while aspirational codes allow space for moral character to develop through the exercise of judgment and the exploration of ethical considerations, their lack of specificity means that they do little themselves to instigate and guide the process of character development, which is instead dependent on educators and experienced practitioners being willing and able to play this role.

In other words, whereas an aspirational code does not anaesthetise moral conscience and undermine moral character, it offers insufficient regulation and guidance, yet its alter ego overemphasises strict regulation to the detriment of professional moral character development and may even undermine established personal moral character. How is one to square the circle and synthesize an aspirational code's reliance on character with a disciplinary code's focus on regulation?

\section{A CONTEXTUAL CODE}

One approach would be to attempt to find an optimum point between overspecificity and over-vagueness that neither precludes disciplinary sanctions nor turns codes into legalistic documents. However, achieving the right balance between 'unenforceability and insubstantiality' ${ }^{110}$ is extremely difficult, not least because - as Zacharias argues ${ }^{111}$ - this will depend on which of a code's possible functions ${ }^{112}$ is seen as most important. Greater specificity is required, for instance, if codes concentrate on directing lawyer behaviour, resolving 'co-ordination problems' or providing a 'defensive ethics' against demanding clients. On the other hand, highly detailed codes tend to undermine the aim of encouraging lawyers to engage in moral introspection or upholding their image as trustworthy professionals. Of course, different parts may fulfil different

108. Flores, above $\mathrm{n} 61, \mathrm{p} 2$.

109. Flores, above n $61, \mathrm{p} 3$.

110. Luban, above $n 97$, at 461 .

111. Above $\mathrm{n}$ 19. See more generally J J White 'Machiavelli and the Bar: Ethical Limitations on Lying in Negotiation' (1980) American Bar Foundation Research Journal 926 at 935.

112. See above nn 19-23 and associated text. 
functions and hence may justify different solutions to the specificity/generality question.

Here a useful distinction can be drawn between ethical norms, which involve questions of what is morally 'right' or 'good', and conduct norms, which relate to matters of etiquette or 'mere regulation', with the latter resembling traffic or VAT regulations in requiring 'knowledge and implementation', but no 'thought and understanding'. ${ }^{113}$ From the perspective of character development, there is little objection to detailed regulation of issues like advertising, insurance requirements, and training contracts. Not raising ethical dilemmas, their resolution is unlikely to impact on character development. By contrast, where ethical dilemmas are raised, such as whether lawyers can refuse representation, how much control to exercise over clients, or when confidentiality can be breached, overly specific rules raise the problems associated with disciplinary codes. Nevertheless, the answer does not simply lie in making these ethical norms less specific. Instead, codes could be divided into two sections or even two separate codes, with the conduct norms taking a disciplinary form and the ethical norms a contextual form.

Not unlike the current codes, the 'contextual' code favoured by Webb and myself ${ }^{114}$ would commence with broad aspirational principles, professional ideals and virtues, requiring lawyers, for instance, to act with integrity, honesty and candour, and to practise in ways which promote the public good. At a second level, it would outline more specific principles and duties, such as respecting client confidences, ensuring equal access to the law, upholding client autonomy etc. Then at a third level it would combine these ideals, virtues, principles and duties with more specific guidance on how they affect the resolution of particular dilemmas. It is here that a contextual code will differ most from the current codes. Instead of either simply stating some general principle or duty or providing categorical answers to highly specific questions a contextual code would set out contextual factors which affect how one might apply the various virtues, ideals, principles relevant to particular ethical issues. As in administrative law, such factors would have to be considered and weighed against each other in reaching a resolution, but they would not by themselves determine the decision. ${ }^{115}$

In addition, the codes could also include commentaries explaining the relevance of the particular virtues, ideals, principles, duties and contextual factors in question, as well as the rulings of professional bodies dealing with requests for guidance on particular ethical dilemmas and disciplinary matters. In this last regard, it is important that contextual codes retain a disciplinary function in order to be taken seriously. Admittedly, some loss of certainty will accompany the move away from detailed norms. ${ }^{116}$ Although the professional bodies do not seem overly concerned about imposing penalties on their

113. Crawley and Bramall, above $\mathrm{n} 82, \mathrm{p} 105$.

114. See above $n$ 36. See also Simon, above $n 35$.

115. Although occasional categorical rules for important ethical obligations would not seriously undermine the advantages of contextualism, it is difficult to think of any which are not also obvious legal obligations (eg the rule against stealing from clients). Even the duty to represent criminal defendants despite moral qualms, I will argue, should be merely a strong presumption rather than a categorical rule.

116. But not as great as might be expected: see Simon, above n 35, pp 70-71. 


\section{Legal Studies}

members under open-ended norms, in order to avoid any unfairness under a contextual code, punishment can be limited to situations where lawyers ignore relevant contextual factors, take into account irrelevant considerations or otherwise act in ways in which no reasonable lawyer would act. Where this is not clearly the case, disciplinary bodies can make declarations for the future, contributing to a rich seam of precedents and a common understanding of how relevant contextual factors should play out, as well as sparking useful debates in the legal community at large. Undoubtedly, this will mean some loss in deterrence. However, this drawback can be offset by developing a more sophisticated and effective regulatory strategy than the half-hearted 'command and control' approach currently adopted. ${ }^{117}$

A clearer idea of a contextual code can be conveyed by showing how it might deal with the controversial issue of whether lawyers should be able to refuse client representation on moral grounds. ${ }^{18}$ In the case of advocates and barristers, the so-called cab-rank rule totally prohibits such refusals, whereas solicitors have absolute discretion to refuse and, apart from the prohibition of racial, sexual and other forms of discrimination, are given no guidance as to how to exercise this discretion (though the role morality of neutral partnership strongly encourages them to represent irrespective of moral considerations). By contrast, a contextual code could first specify the virtues, ideals and principles relevant to the issue of client selection. These would include the traditional justifications for lawyers providing representation notwithstanding moral misgivings: the procedural system's dependence on two zealous adversaries; the fact that representation may be necessary to enhance individual dignity and autonomy; the idea of equal access to law; and the need to protect the vulnerable, the unpopular and the powerless. However, also included could be a principle of moral integrity which stresses that lawyers are implicated in, and hence morally responsible for, all harmful actions taken on behalf of clients; that they cannot pass on moral responsibility either to clients, whom they have freely chosen to represent, or to the profession, which they have voluntarily entered.

Then in guiding lawyers to decide how these principles should play out in particular cases, the code's third level could require consideration of the following contextual factors: ${ }^{119}$

- the relevant material, emotional and psychological interests, desires and needs of those involved in and affected by legal representation;

- the respective harms likely to ensue to prospective clients, those associated with them, third parties, the legal system, the general public, the environment, the individual lawyer and the legal profession depending on whether representation is or is not provided;

- the balance of power between lawyer and prospective client, and between the latter and any opponent and affected others;

117. See Nicolson and Webb, above $\mathrm{n} 1$, ch 4 ; J Webb and D Nicolson 'Institutionalising Trust: Ethics and Responsive Regulation of the Legal Profession' (1999) 2 Legal Ethics 148. 118. The following is based on Nicolson and Webb, above $n 1$, chs 6-8 passim.

119. Cf Simon, above $\mathrm{n} 35$, who limits his relevant factors to those which promote (legal as opposed to substantive) justice, by enabling lawyer to vindicate a case's 'legal merits'. Space constraints preclude a full criticism of this narrow view of justice, but see Nicolson and Webb, above n 1, p 220. 
- whether the lawyer's moral objection is to the client's objectives, the tactics which might be used to achieve these, or merely to the client him or herself because of his or her beliefs and past actions; and

- how certain the lawyer is about the client's moral beliefs and the facts relevant to the above factors.

However, a contextual code need not stop there. Guidance could also be given on how these contextual factors might play out in particular areas of practice. Thus, at one extreme, the code might stress that a combination of power imbalances between accused and the state, the potentially disastrous consequences of criminal convictions and the danger posed to civil liberties generally if defendants' rights are ignored and the innocent are convicted generate a very strong presumption in favour of acting for criminal accused. At the other extreme, there are no particular reasons why lawyers should have to swallow their ethical objections when companies seek representation in activities like lobbying where lawyers are not particularly required. Where, however, civil litigation is involved and particularly where it has reached court, citizens' need for lawyers to help them assert their rights and possibly also autonomy and dignity, and lawyers' monopoly of advocacy rights swing the balance more towards providing representation despite moral objections, especially where power imbalances between the prospective client and opponent resemble criminal cases.

When compared with the current codes, the contextual approach has advantages in relation to both the issue of client representation and the more general aim of fostering a more ethical profession through character development. As regards the former, an approach which requires lawyers to think through the reasons for and against representation is likely to ensure stronger commitment to client interests than one where lawyers provide representation solely because of threatened sanctions or the promise of financial rewards. An interesting paradox in the current position is that while the cab-rank rule and neutral partisanship more generally are justified as ensuring protection to the weak, the unpopular and the impoverished, ${ }^{120}$ these are precisely the people that many lawyers try to avoid representing ${ }^{121}$ and who, when represented, frequently receive lack-lustre assistance. ${ }^{122}$ Rather than force unwanted clients on unwilling lawyers, it ought to be recognised that the obligation to provide representation for those in need falls on the profession as a whole, which should collectively ensure that it is fulfilled. ${ }^{123}$

More generally, by exposing law students to the various dilemmas and moral considerations that arise in different practice arenas, contextual codes can help them make ethically informed choices about what area of law to practise. This is probably their most significant ethical decision, determining both the type of moral dilemmas they are likely to face and the likely constraints on their

120. See the references in Nicolson and Webb, above n 1, p 193 nn 84-86.

121. Nicolson and Webb, above n 1, p 204 n 180.

122. See Baldwin and McConville, McConville, Davis, all above $\mathrm{n} 73$.

123. Hutchinson, above $\mathrm{n} 34$, ch 5; D Nicolson 'Afterword: In Defence of Contextually Sensitive Moral Activism' (2004) 7 Legal Ethics 269 at 270-272, responding to A Boon 'Cause Lawyers and the Alternative Ethical Paradigm: Ideology and Transgression' (2004) 7 Legal Ethics 231 at 250-268. 


\section{Legal Studies}

ability to display moral integrity. ${ }^{124}$ It is therefore essential that aspiring lawyers consider these dilemmas and constraints before they make career choices and before financial rewards, career prospects and job satisfaction overwhelm their moral consciences. Moreover, actual application of a contextual code in roleplaying or law clinics will hopefully also start the development of professional moral character. Such character would continue to strengthen as lawyers repeatedly consider the code's wide range of relevant considerations in resolving dilemmas throughout their careers and are periodically exposed to novel contextual factors which have to be compared with more familiar factors in resolving moral dilemmas.

\section{CONCLUSION}

Although I have argued that development of professional moral character and its support by a contextual code provides the most profitable route to an ethical legal profession, I am under no illusion that the task is an easy one. Its difficulty flows from the fragility of moral character in general and the difficulties of remaining virtuous in legal practice.

As regards the former, some philosophers have argued that social psychology experiments in which subjects were surprisingly susceptible to situational factors encouraging harmful or discouraging helpful behaviour show that character dispositions do not exist ${ }^{125}$ or that at best there are only 'local traits' which provide reliable behavioural dispositions for highly specific situations. ${ }^{126}$ Although these arguments have been vehemently contested as misinterpreting both the experiments and the concept of character, ${ }^{127}$ virtue ethicists have acknowledged that the fully virtuous moral agent predictably acting morally in the face of contrary situational pressures and temptations is far from the norm. Instead, full virtue is an ideal to be strived for and achieved, if at all by, over time and by degrees. Indeed, some now agree that considerable attention needs to be paid to exploring how moral agents might best be able to resist situational pressures and temptations to act immorally.

124. Hutchinson, above $\mathrm{n} 34, \mathrm{p} 73$.

125. G Harman 'Moral Philosophy Meets Social Psychology: Virtue Ethics and the Fundamental Attribution Error' (1999) 99 Proceedings of the Aristotelian Society 315, 'The Nonexistence of Character Traits' (2000) 100 Proceedings of the Aristotelian Society 223 and 'No Character or Personality' (2003) 13 Business Ethics Quarterly 87.

126. J M Doris 'Persons, Situations, and Virtue Ethics' (1998) 32 Noûs 504 and Lack of Character: Personality and Moral Behaviour (Cambridge: Cambridge University Press, 2002); P Vranas 'The Indeterminacy Paradox: Character Evaluations and Human Psychology’ (2005) 39 Noûs 1.

127. N Athanassoulis 'A Response to Harman: Virtue Ethics and Character Traits.' (2000) 100 Proceedings of the Aristotelian Society 215; M Merritt 'Virtue Ethics and Situationist Personality Psychology' (2000) 3 Ethical Theory and Moral Practice 365; J J Kupperman 'The Indispensability of Character' (2001) 76 Philosophy 239; G Sreenivasan 'Errors about Errors: Virtue Theory and Trait Attribution' (2002) 111 Mind 47; C Miller 'Social Psychology and Virtue Ethics' (2003) 7 The Journal of Ethics 365; R C Solomon 'Victims of Circumstances? A Defense of Virtue Ethics in Business' (2003) 13 Business Ethics Quarterly 43; R Kamtekar 'Situationism and Virtue Ethics on the Content of Our Character' (2004) 114 Ethics 458; L Besser-Jones 'Social Psychology, Moral Character, and Moral Fallibility' (unpublished manuscript). 
This is particularly apposite in the case of lawyers. Of the various situational pressures they face, while the ideology of neutral partisanship has remained largely unchanged and there has even been some weakening of the adversariality of legal proceedings, ${ }^{128}$ the commercialisation, specialisation and bureaucratisation of legal practice has grown apace. ${ }^{129}$ Accordingly, legal practice has come to prioritise the financial bottom line and the exercise of technical skills over ethics more than ever before. Moreover, in large practice settings, moral responsibility may now 'float' ${ }^{130}$ throughout the organisation or 'fall between the players'. ${ }^{131}$ In this light, it is hardly surprising that practising lawyers apparently exhibit a lower stage of moral development than law graduates. ${ }^{132}$

This suggests that current approaches to ethical codes are not working. But it might also be taken to suggest that the current climate of legal practice, along with the general fragility of moral character, its alleged fragmentation into local traits, and the apparent rarity of fully virtuous moral agents preclude placing any faith in contextual codes and the development of moral character. For two reasons, I think that such a response is misplaced.

One is that legal practice in fact requires stable local, rather than global, moral traits. Particularly due to increasing specialisation, lawyers are not required to act virtuously across a wide range of situations, but only in relatively few routine situations. A contextual code will inform legal neophytes of the ethical considerations relevant to various practice areas, thus guiding and adding an ethical dimension to their choice of practice area, and then make routine the application of various contextual considerations to specific moral dilemmas as they arise. In this way, it is possible that fixed behavioural dispositions of a moral nature may relatively soon emerge.

Secondly, the potential fragility of lawyers' moral character and its susceptibility to the situational pressures and temptations of legal practice are not problems which are exclusive to a character-based approach to the 'how' of legal ethics. Any alternative to a contextual code and a focus on character development needs to ensure that lawyers not only perceive moral problems when they arise and know how to resolve them, but also care about acting morally and do so despite situational obstacles.

The most plausible option is the intensification of a command and control strategy. This requires, on the one hand, subjecting the increasingly complex problems of an increasing diversified legal profession to ever more detailed rules, and constantly revising them as conditions and ethical priorities change, and, on the other hand, a much greater commitment to the detection and prosecution of disciplinary offences. Whether the professional bodies have the inclination to devote the necessary resources to such increased rule-making and enforcement is a moot point, though the English and Welsh Law Society's

128. See eg D Webb 'Civil Advocacy and the Dogma of Adversarialism' (2004) 7 Legal Ethics 210; L Webley 'Divorce Solicitors and Ethical Approaches - The Best Interests of the Client and/or the Best Interests of the Family?' (2004) 7 Legal Ethics 231.

129. See the works cited in above $\mathrm{n} 76$.

130. Bauman, above n 39, pp 19-20.

131. D Luban Lawyers and Justice: An Ethical Study (Princeton, NJ: Princeton University Press, 1988) pp 123-125.

132. Webb, above n 78, p 271. 


\section{Legal Studies}

recent proposals and the other professional bodies initial reluctance to promulgate rules do not bode well. But even if the commitment existed, we have seen that it is unlikely that even detailed rules can cover all situations or the professional bodies can detect and successfully prosecute all breaches. Yet where the rules run out or sanctions appear ineffective, I have argued that the reliance on detailed rules and the threat of sanctions will leave lawyers with inferior judgment capacities, a narrower range of moral sensibilities and a reduced personal commitment to moral behaviour.

Arguably, if professional moral character had as long to develop as personal moral character and was supported by as many powerful institutions, then a combination of detailed rules and disciplinary sanctions might just be a plausible means to making lawyers moral. However, professional moral character must develop over a much shorter period with far weaker socialisation institutions, and possibly even greater countervailing pressures and temptations than those that challenge personal moral dispositions. Consequently, an approach to ethics which directly engages with character development seems far better suited to ensuring moral behaviour by lawyers and it in this process that a contextual approach to code design can play an important role. 